\title{
Low Flow Trends and Frequency Analysis in the Blue Nile Basin, Ethiopia
}

\author{
Kidist Assefa1, Mamaru A. Moges ${ }^{2,3^{*}}$ \\ ${ }^{1}$ Amhara Water Irrigation and Energy Bureau, Bahir Dar, Ethiopia \\ ${ }^{2}$ Faculty Civil and Water Resources Engineering, Bahir Dar Institute of Technology, Bahir Dar University, Bahir Dar, Ethiopia \\ ${ }^{3}$ Blue Nile Water Institute, Bahir Dar University, Bahir Dar, Ethiopia \\ Email: ^mamarumoges@gmail.com
}

How to cite this paper: Assefa, K. and Moges, M.A. (2018) Low Flow Trends and Frequency Analysis in the Blue Nile Basin, Ethiopia. Journal of Water Resource and Protection, 10, 182-203.

https://doi.org/10.4236/jwarp.2018.102011

Received: January 26, 2018

Accepted: February 25, 2018

Published: February 28, 2018

Copyright (c) 2018 by authors and Scientific Research Publishing Inc. This work is licensed under the Creative Commons Attribution International License (CC BY 4.0).

http://creativecommons.org/licenses/by/4.0/

\begin{abstract}
Low flow analysis provides crucial information for the planning and design water resource development, risk assessment and environmental flow management. Understanding the low flow regimes and evaluating the magnitudes for incorporating in water resources management is vital for the countries like Ethiopia where demand for water is increasing. However, there were hardly enough studies in understanding the trends of low flow and frequency analysis. Therefore, this study focuses on evaluation of the trends in low flows and regional low flow analysis in the Blue Nile Basin, Ethiopia. In order to carry out the study, 15 river sub-basins in the Blue Nile Basin were selected based on the long term data availability and presence of quality of data. The 3-day sustained low flow (3d-slf), the 7-day sustained low flow (7d-slf) and the 14-day sustained low flow (14d-slf) models were used to extract the data from the daily time series stream data obtained from MoWIE. Trends in low flow were analyzed separately by using Mann-Kendall (MK) trend test. Low flow frequency analysis was used to estimate the long term low flow quantiles. In addition, regional analysis for estimating the quantiles for ungaged catchments was also developed based on the regional growth curve and catchment characteristic of drainage basins. The results indicated that $3 \mathrm{~d}$-slf, $7 \mathrm{~d}$-slf and $14 \mathrm{~d}$-slf models of low flow series indicated no significant difference for each station at $95 \%$ CI. Out of the 15 selected stations, 12 of stations have indicated decreasing; two stations indicated increasing and remaining one station with no trend. Mainly decreasing trend was associated with the land cover and climate change which results in increasing runoff and evapotranspiration respectively. Weibull distribution-GEV and LGN was found best fit based on the L-Moment Ratio Diagram (L-MRD). Hence quantile estimations have indicated diminishing magnitudes of low flow quintiles for $2-500$ years return
\end{abstract}


periods. Regional low frequency analysis has provided a very good relationship between discharge and catchment characteristics with an $\mathrm{R}^{2}$ of 0.72 . Where area $(\mathrm{A})$ and rainfall $(\mathrm{R})$ followed by slope were found sensitive to compute in developing the regional region equations between mean low flows and the physiographic data. This study indicated that there needs to be a new water management scenario and adaptation mechanism of climate change and land use land cover dynamics for utilizing water resource in the Blue Nile Basin.

\section{Keywords}

Mann-Kendall, Low Flow, L-MRD, PWM, Regionalization, Blue Nile Basin

\section{Introduction}

Low flow is the smallest sustained average daily flow rate or volume with time [1]. It is an important part of the natural flow regime of rivers where the water resource planning and design consider its spatial and temporal variability. Low flow analysis is important for basin management, river abstraction, effluent dilution, navigation purposes, ecosystem protection and environmental flow limit [2]. Sometimes it uses as an indicator of hydrological drought during the continuous low-flow period in one year [3]. According to [2] low flow information is needed in three situational cases 1) for water resource development, 2) to execute the daily decisions on managing the water resource development during operational phases, and 3) when there is a current need to decide on the operations based on the estimations of the future stream flows. Nevertheless, very often in most part of the rivers the low flows are indicating signs of decreasing flow rate and volume.

Decreasing in low flow would impact the environmental flow in a given ecosystem and affect multi-purpose operations which depend on that water system such as river and lakes. It could happen due to different ways, for instance groundwater pumping close to the head of a perennial river during the dry season [4], due to the dynamics in vegetation cover as a result of deforestation [5], due to the an expansion of irrigation which requires withdrawal of water from rivers in dry seasons [6]. Reduced low flow may also cause an impairment of water quality, and affect river ecological status and navigation and power supply sectors [7]. To understand the causes and take remedial action for the sustainable utilization of the low flows the dynamics in low flows in a river system should be evaluated, which could include quantifying the trend of low flow quantiles, and developing regional curves (ungaged catchments) is a very important approach for proper management of the water resources.

Low flow frequency curves describe the relationship between the magnitude of river low flows and the recurrence interval or return period. It can also be derived from data from monitoring stations and regionalized for use at any location along the basin's river network, by relating the spatial differences to geo- 
graphical regions and to variations in upstream sub-basin characteristics. Low flow frequency analysis and predictions generally have to deal with the inadequacy or deficiency of observations for the site of interest [8]. Information for an ungaged site may be obtained either by means of deterministic models or by regionalization techniques based on available observed flow records from gauged stations.

In the Blue Nile Basin an increase in population over the past few years has put great pressure on the natural resources, where it has led to increase in demand for more water and agricultural land and resulting deforestation [9] [10] [11]. In the under this study, recently there are observations on drying out of some rivers, where the low flow is becoming no flows. However there have not been many studies carried out especially in evaluating trends and estimation technique for long term quintiles of low flow. Hence understanding the low flow trends and develop estimation techniques for ungaged catchments is paramount. In addition evaluation of low flow is important for water resource development and management for sustainable and proper utilization of water resource and maintaining the environmental flows. Therefore this study presents trends and frequency analysis of the low flow in the selected rivers in the Blue Nile Basin, Ethiopia. In addition regional low flow analysis to estimate the low flow quantiles from the ungaged catchments was also carried out in this study.

\section{Materials and Methods}

\subsection{Description of the Study Area}

The Upper Blue Nile River "Abbay" basin (Figure 1) lies in the western part of Ethiopia between latitudes of $7^{\circ} 45^{\prime} \mathrm{N}$ and $12^{\circ} 46^{\prime} \mathrm{N}$ and longitudes of $34^{\circ} 05^{\prime} \mathrm{E}$ and $39^{\circ} 45^{\prime} \mathrm{E}$. The basin has an estimated area of $199,812 \mathrm{~km}^{2}$. The basin covers $17 \%$ land area of the country and lies in three national regional states where $46 \%$ of the basin area is Amhara, 32\% in Oromia and 22\% in Binishangul-Gumuz. It Locally the climate in the basin is subdivide as the dry season "Bega" from October to the end of February; the short rain period "Belg" from March to May and the long rainy period "Kiremt" from June to September, highest amount of rainfall in July and August. The average annual rainfall ranges from 1200 $\mathrm{mm} /$ year $-1800 \mathrm{~mm} /$ year [12]. The rivers flow in the basin was described by the rainfall variability [13]. The 100 year mean annual flow volume of the Blue Nile river (monitored at El Diem) was nearly $50 \mathrm{Bm} 3$ [14] where 8\% flow volume was observed at Bahir Dar (at Cherechra gaging station) and $32.9 \%$ was at Kessie [12]. Annual stream flow variability in the basin ranges up to maximum of $20 \%$ [15]. The basin has rigid topography with steep slopes which governs the flow other the Blue Nile River. The main land use types in the basin are dominantly cultivated land which has been by large changed from forest in the past six decades. According to [16] the main soil types in the basin include volcanic vertisols or latosols. The geology of the Blue Nile Basin in highland area was composed of 


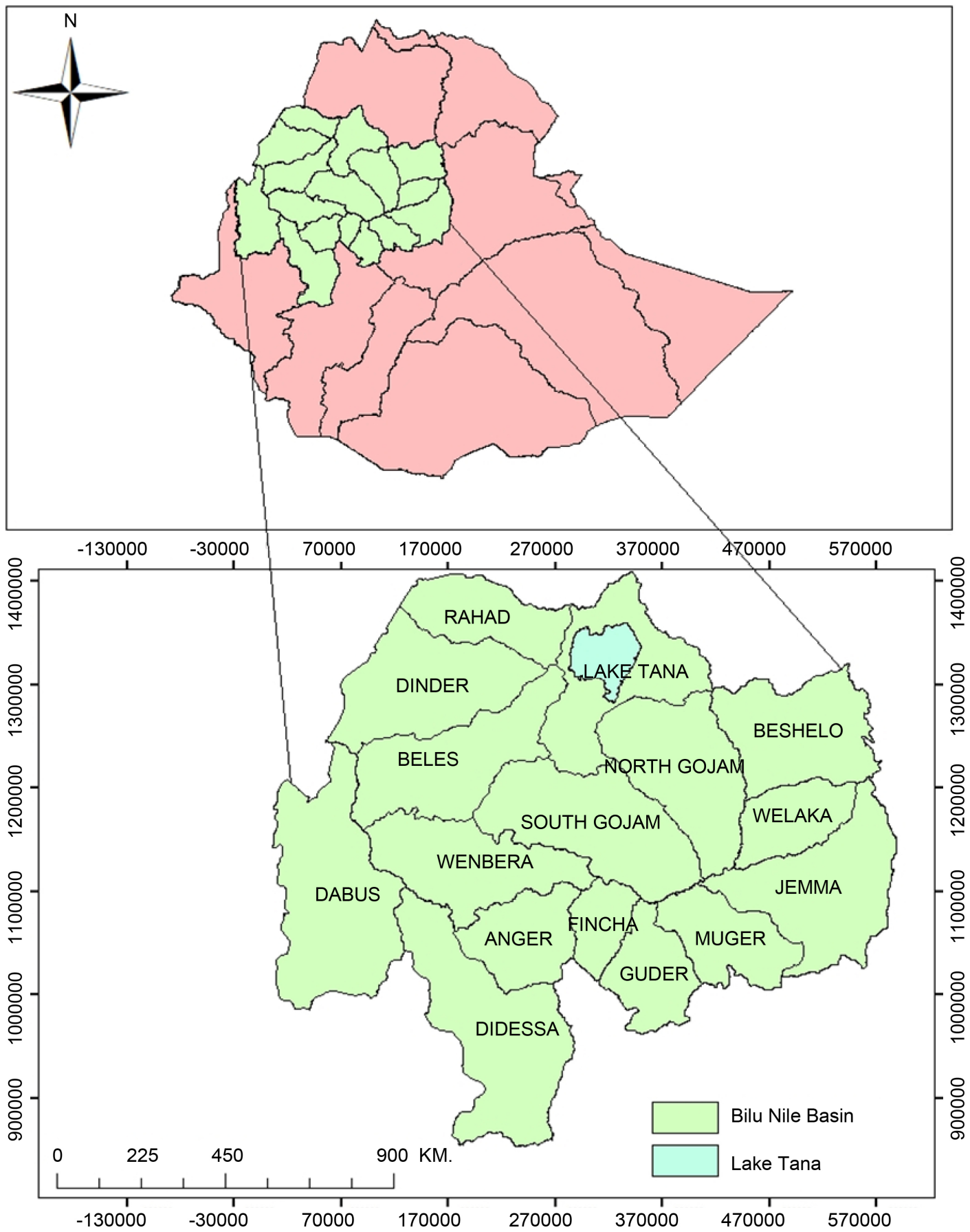

Figure 1. Location map of the study area.

basic rocks (dominantly basalts) and the lowland part near the Sudanese border was composed of basement complex rocks and metamorphic rocks [17].

\subsection{Methodology}

The general methodology of this study follows four main approaches 1) extracting the low flow data and data quality analysis, 2) analyzing and evaluating the trends of low flow data from the selected 15 flow stations in the Blue Nile Basin, 
3) low frequency analysis for selected station in the basin and 4) regionalization of the low flow for estimating the quantiles for the ungaged catchments.

\subsubsection{Data Availability}

Data needed for this study were collected from different organization in order to use for low flow trends, frequency and regional frequency analysis. Limited record length was typically a major challenge interpret the results of trend analysis, as there are often few homogeneous records on which the statistical analysis could be carried out. The stream flow data used for the low flow analysis was obtained from the Ministry of Water Irrigation and Electricity (MoWIE). Among the functional stream flow stations in the basin 15 river gaging stations (Figure 2, Table 1) were selected. The selection was based on 1) the long record of data, less missing records and functionality and 2) consideration of the spatial distributions of gaging stations and sub basins in the basin. Duration of data availability for the low-flow analysis used for this study ranged with 10 to 42 years of record length. The missing data in the daily stream flow was carried out based on the extent of missing data. Station-average method (for missing data less $10 \%$ ) and normal ratio method (missing data higher than $10 \%$ ) has been used [18] to infill the missed data. The low flow data extraction was based on the 3 day sustained low flow (3d-slf), the 7 day sustained low flow (7d-slf) and the 14 day sustained low flow (14d-slf) for the selected stations.
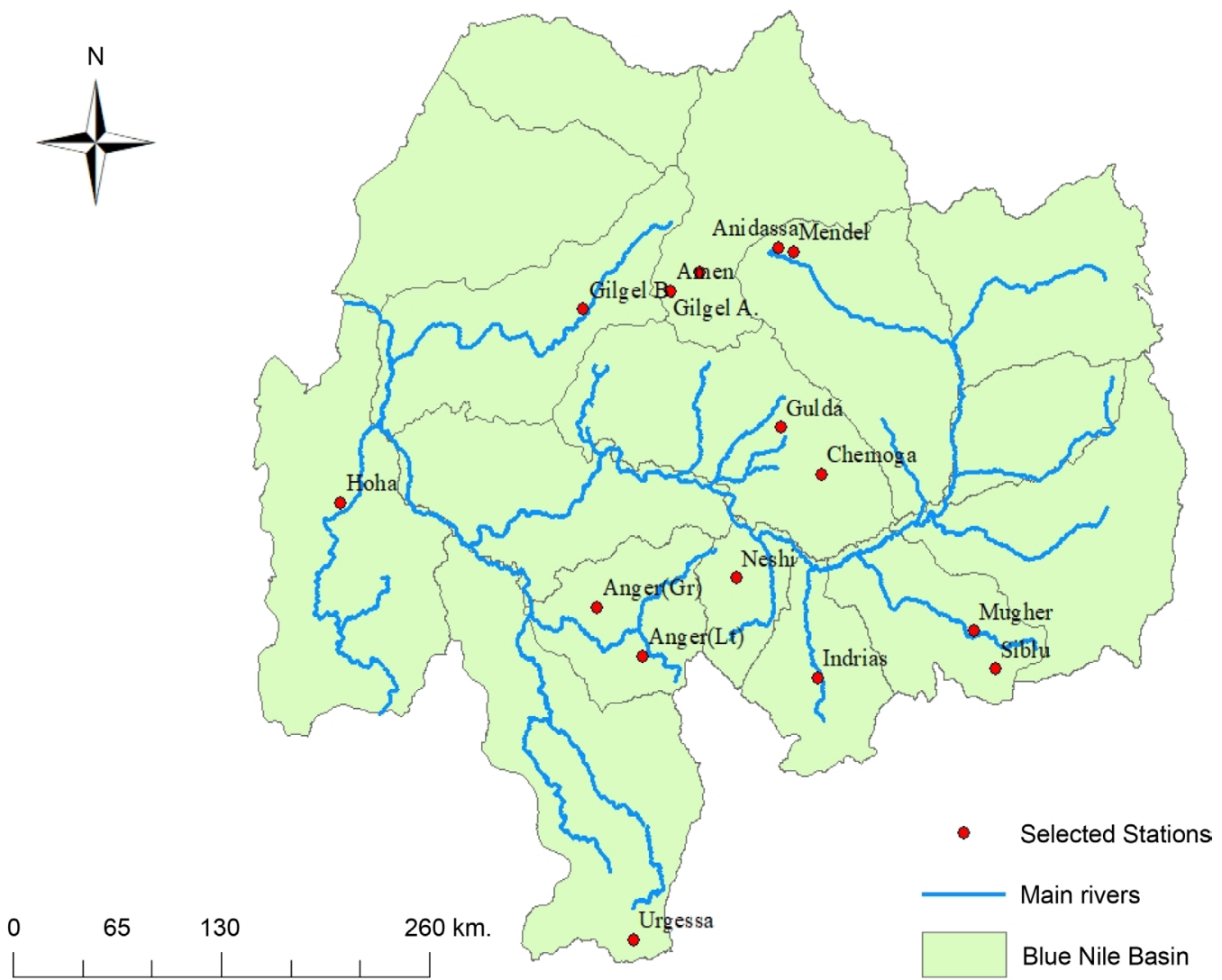

Figure 2. Selected stations in the Blue Nile Basin. 
Table 1. Data availability and source for the selection of stations.

\begin{tabular}{|c|c|c|c|c|c|}
\hline \multirow[t]{2}{*}{ ID } & \multirow[t]{2}{*}{ River/Sub basin } & \multirow[t]{2}{*}{ Gaging location } & \multicolumn{2}{|c|}{$\begin{array}{c}\text { Geographical } \\
\text { position in UTM }\end{array}$} & \multirow{2}{*}{$\begin{array}{l}\text { Area } \\
\mathrm{km}^{2}\end{array}$} \\
\hline & & & North & East & \\
\hline 1 & Amen & Dangila & $1,246,201$ & 267,104 & 89.15 \\
\hline 2 & Andassa & Bahir Dar & $1,271,589$ & 334,578 & 596.38 \\
\hline 3 & Angar-greater & Nekemte & $1,060,930$ & 220,413 & 1099.03 \\
\hline 4 & Angar-lower & Nekemte & $1,032,779$ & 249,835 & 619.66 \\
\hline 5 & Chemoga & Debremarkos & $1,138,754$ & 361,295 & 364.25 \\
\hline 6 & Gelgel abbay & Marawi & $1,257,136$ & 285,380 & 1656.00 \\
\hline 7 & Gelgel beles & Mandura & $1,235,578$ & 212,387 & 676.56 \\
\hline 8 & Gulda & Dembecha & $1,166,512$ & 335,870 & 249.28 \\
\hline 9 & Hoha & Asossa & $1,122,346$ & 678,950 & 161.12 \\
\hline 10 & Indris & Guder & $1,019,788$ & 358,631 & 118.13 \\
\hline 11 & Mendel & Tis Abbay & $1,268,152$ & 364,364 & 91.35 \\
\hline 12 & Muger & Chancho & $1,056,459$ & 443,536 & 549.49 \\
\hline 13 & Neshi & Shambo & $10,781,717$ & 308,031 & 322.43 \\
\hline 14 & Sibilu & Chancho & $1,028,748$ & 467,164 & 380.12 \\
\hline 15 & Urgessa & Gembe & 897,894 & 232,531 & 19.11 \\
\hline
\end{tabular}

\subsubsection{Trends in Low Flow}

Evaluating the presence and absence of trends in low flow for the selected stations was carried out by using the Mann and Kendall (MK) trend test [19]. MK trend test (Equations (1)-(3)) evaluates and indicates the absence and presence of the monotonic increasing/decreasing trend. MK trend test was a non-parametric rank-based [12] method which was widely used to test the randomness against trend in hydro-climatologically time series data [20]. The existence of trend was explained as no trend, increasing trend and decreasing trend based on the significance level of test static [21]. It does not require assumptions about the statistical distribution of the data. The test statistic, $S$ (Equation (1)) calculates as the sum of the difference between data points and the associations between samples which is referred as Kendal tau to show the presence or absence of trend. A positive value of $S$ indicates an increasing trend while a negative value shows a decreasing trend [22].

$$
S=\sum_{i=1}^{n-1} \sum_{j=i+1}^{n} \operatorname{sgn}\left(x_{j}-x_{i}\right)
$$

where $x_{j}$ and $x_{i}$ are the daily values in days' $j$ and $i, j>i$, respectively and

$$
\operatorname{sgn}\left(x_{j}-x_{i}\right)= \begin{cases}1 & \text { if } x_{j}-x_{i}>1 \\ 0 & \text { if } x_{j}-x_{i}=0 \\ -1 & \text { if } x_{j}-x_{i}<0\end{cases}
$$

If $n<10$, the value of $|S|$ is compared directly to the theoretical distribution of $S$ derived by Mann and Kendall. 


$$
Z_{S}= \begin{cases}\frac{S-1}{\sqrt{V(S)}} & \text { if } S>0 \\ 0 & \text { if } S=0 \\ \frac{S+1}{\sqrt{V(S)}} & \text { if } S<0\end{cases}
$$

The MK trend test $Z_{S}$ statistics (Equation (2)) determines the presence of decreasing or increasing trend if is negative and positive respectively. The test statistic $Z_{S}$ is also used a measure of significance of trend. If $\left|Z_{s}\right|$ is greater than $Z_{\alpha / 2}$, where $\alpha$ represents the chosen significance level (e.g.: $5 \%$ with $Z_{0.025}=1.96$ ) implying that the trend is significant [23] and $V(S)$, the variance of statistic was given as in Equation (3).

$$
V(S)=\frac{n(n-1)(2 n+5)-\sum_{t=1}^{m} t_{i}\left(t_{i}-1\right)\left(2 t_{i}-5\right)}{N}
$$

\subsubsection{Low Frequency Analysis}

The purpose of low frequency analysis in this study was to estimate the long term quantiles of for different return periods and regionalize estimations in order to compute the low flows for ungaged estimates. Detail procedure of the frequency analysis used in this study was presented as follows.

1) Selection of low flow models

The $\mathrm{K}$ days sustained low flow method of data extracting was used to prepare the data for low flow trends and frequency analysis for the selected stations. Where the lowest K day's stream flow data per year has been averaged to obtain $\mathrm{k}$ days sustained (mean) low flow (Kd-slf) as presented in equation 4 . Three different models have been used for selecting the low flow data series for this study including the three days-sustained low flow (3d-slf) model, the seven days-sustained low flow (7d-slf) model and the fourteen days sustained low flow (14d-slf) model.

$$
\text { Kd-slf }=\frac{\sum_{i=n-2}^{n} x_{i}}{K}
$$

where $K$ is the number of sustained days, $n$ is the number of data in time series (365 and 366 in leap years) and $X_{i}$ the daily time series of stream flow $\left(\mathrm{m}^{3} / \mathrm{s}\right)$

2) Data quality analysis

Checking the data quality of the $K$ day sustained low flow data series was vital as it enhances the analysis. Some of the common methods to assess the data quality carried out before the low flow analysis includes outliers and independency. Where the outlier test evaluates the presence of extreme (high and low) values in the low flow data series was carried out by using [24]. The test for independency was also carried out by [25]. Homogeneity and stationarity test of data quality for the n-day sustained low flow data series was also carried out by using [26] method. 


\section{3) L-moments}

[27] stated that the L-moments as the summary statistics for probability distributions and data samples. Which are analogous to ordinary moments and provide measures of location, dispersion, skewness, kurtosis, and other aspects of the shape of probability distributions or data, where these are computed from linear combinations of the ordered data. It's properties hold in a wide range of practical situations [27]. For instance the asymptotic approximations for sampling distributions are better for $L$-moments than the ordinary moments. It also provides better identification of the parent distribution generated by a particular data sample. L-moments can characterize a wider range of distributions, compared to the conventional moments. For this study the L-moments have been used for selecting the best fit probability distribution and during parameter estimation for each station.

4) Selection probability distribution

a) L-Moment Ratio Diagram (L-MRD)

One of the main applications of L-moments is identification of the probability distribution of the observed phenomena using the L-MRD. This was based on relationships between the L-moment ratios [28]. A theoretical diagram based on $L-C s\left(\tau_{3}\right)$ versus $L-C k\left(\tau_{4}\right)$, was used similar to the conventional MRDs to identify appropriate distributions. For a given region, the sample L-moment ratios $\tau_{3}$ and $\tau_{4}$ for each station as well as their regional average are plotted on the L-moment ratio diagram. A suitable parent probability distribution was identified which averages the scattered data and around which the data spread consistently. For this study the L-moments were used to identify the parent probability distributions. Since the L-MRD was based on unbiased sample quantities which have to be corrected for bias. L-MRD plot as fairly well separated groups and permit better discrimination between the distributions.

5) Selection of parameter estimation method

After selecting the best fit probability distribution for each station the parameters of probability distribution could be estimated in a number of estimation techniques. Some of methods of parameter estimation [28] indicated the most commonly used parameter estimation methods were a) Method of Moments (MOM), b) The Maximum Likelihood Method (MLM), c) The Probability Weighted Moments (PWM) methods. For this study Probability Weighted Moment (PWM) [29] method of parameter estimation was chosen due to its applicability and ease of implementing for regional parameter and quantile estimation [28]. The method was often defined by plotting position estimates of $M_{1, o, s}$ and $M_{1, r, 0}$ in Equations (5)-(6).

$$
\begin{gathered}
a_{s}=\alpha_{s}=M_{1, o, s}=\frac{1}{N}=\sum_{i=1}^{N}(1-F)^{s} X_{i} \\
b_{r}=\beta_{r}=M_{1, r, 0}=\frac{1}{N}=\sum_{i=1}^{N} F i^{r} X_{i}
\end{gathered}
$$

where 


$$
\begin{aligned}
\alpha_{0}=\beta_{0} & \beta_{0}=\alpha_{0} \\
\alpha_{1}=\beta_{0}-\beta_{1} & \beta_{1}=\alpha_{0}-\alpha_{1} \\
\alpha_{2}=\beta_{0}-2 \beta_{1}+\beta_{2} & \beta_{2}=\alpha_{0}-2 \alpha_{1}+\alpha_{2} \\
\alpha_{3}=\beta_{0}-3 \beta_{1}+3 \beta_{2}-\beta_{3} & \beta_{3}=\alpha_{0}-3 \alpha_{1}+3 \alpha_{2}-\alpha_{3}
\end{aligned}
$$

$F$ in Equations (5)-(6) can be estimated from the plotting position formulas among the many for this specific study it was estimated by [27] as indicated in Equation (7).

$$
F=\frac{i-a}{N+1-2 a}
$$

Hosking (1986 and 1990) indicated the L-moments, which are linear functions of PWMs and defined in terms of the PWMs $\alpha$ and $\beta$ by Equations (8)-(11)

$$
\begin{gathered}
l_{1}=\alpha_{0}=\beta_{0} \\
l_{2}=\alpha_{0}-2 \alpha_{1}=2 \beta_{1}-\beta_{0} \\
l_{3}=\alpha_{0}-6 \alpha_{1}+6 \alpha_{2}=6 \beta_{2}-6 \beta_{1}+\beta_{0} \\
l_{4}=\alpha_{0}-12 \alpha_{1}+30 \alpha_{2}-20 \alpha_{2}=20 \beta_{3}-30 \beta_{2}+12 \beta_{1}-\beta_{0}
\end{gathered}
$$

where the ratio of L-moments $\left(\tau_{r}\right)$ used in this study were analogous to conventional moment ratios as defined by [27] as indicated in Equations (12) and (13)

$$
\begin{gathered}
\tau=\frac{l_{2}}{l_{1}} \\
\tau_{r}=\frac{l_{r}}{l_{1}} \text { for } r \geq 3
\end{gathered}
$$

where $l_{1}$ is a measure of location, $\tau$ is a measure of scale and dispersion $(L C V), \tau_{3}$ is a measure of skewness $(L C s)$, and $\tau_{4}$ is a measure of kurtosis $(L C k)$ defined by Equations (14)-(16)

L-Coefficient of variation $(L C V)=\tau=\frac{l_{2}}{l_{1}}$

L-Coefficient of skewness $(L C s)=\tau_{3}=\frac{l_{3}}{l_{2}}$

L-Coefficient of kurtosis $(L C k)=\tau_{4}=\frac{l_{4}}{l_{2}}$

6) Quantile estimation of low flows

The estimated parameters for specific probability distributions were used to calculate quantiles of low flows for different return periods. This was carried out by using the distribution function, in which the parameters of the distribution were replaced by their estimates and the relationship between return periods $(T)$ and probability of exceedance $(F)$. In low flow frequency analysis the assumption for the relationship between the low flows quantiles with return period was based on the exceedance probability as indicated in Equation (17).

$$
F=\frac{1}{T}
$$


where $F$ is the probability distribution function and $T$ is the return period

\subsubsection{Regional Low Flows for Ungaged Catchments}

In order to carry out the regional low flow analysis initially the homogeneous group of stations has to be identified and categorized by using the L-MRD and coefficient of variation of coefficient of variation (C-C) test. The station year method was used for estimating the standardized long term quantiles for developing the regional frequency curve. The station year methods pull the standardized low flow values as one station for each homogenous group. The best probability distribution for each homogenous group (pulled standardized data) was fit by using similar to procedures as discussed in above sections. Using this probability distribution, the long term standardized quantiles was estimated for various return periods such as $2,10,25,50,100,200$ and 500 years. The regional growth curve was established as the relationship between the standardized quantiles and return periods for each return period. Hence the estimated standardized quantile was used to compute the normal low flow quantiles for both gaged and ungaged stations was using the relationship under Equation (18).

$$
Q_{T}=\bar{Q}^{*} X_{T}
$$

where $Q_{T}$ is the low flow for T-years of return period, $\bar{Q}$ is the n-day sustained average annual low flow, $X_{T}$ standardized quantile of for $\mathrm{T}$ years return period.

To compute the low flow quantiles for ungaged catchment using equation 18 , the relationship between the $\mathrm{n}$-day sustained average annual low flow of gaged stations and physical catchment characteristics has to be set up. Developing the relationship between the sustained average annual low flow and the catchment characteristics was also used for predicting the low flow quantiles at any point where the regional frequency curve was derived. In order to carry out the prediction, there are a number of measurable physical characteristics of catchments that could have significant relationship with the $n$-day sustained average low flow. Several physical catchment characteristics have been used for developing models to simulate the n-day sustained annual low flows for the ungaged catchments. The non-linear regression (Equation (19)) was used to develop a relationship between the average annual low flow for ungaged catchments in Blue Nile River basin. For this study the mainly used(easily measurable) physical catchment characteristics such as area $(A)$, rainfall $(R)$, slope $(S)$, stream length $(L)$ and shape factor $(F)$ was considered as independent variables.

$$
\bar{Q}=C A^{a} S^{s} R^{r} L^{t} F^{t}
$$

where $\bar{Q}$ is the average $n$ day sustained low flow each station, $A$ is the drainage of the selected station in square kilometers, $S$ is average Slope expressed in percentage, $R$ is the mean annual rainfall in millimeters, $L$ is the length of stream, $F$ is shape factor of the catchments. The parameters $a, r, s, t$ and $c$ of physical catchment characteristics were also estimated using multiple non-linear regression technique. 


\section{Results and Discussion}

\subsection{Data Analysis and Quality}

The three low flow data extraction models (3d-slf, 7d-slf and 14d-slf) in the selected 15 stations have been summarized and presented in Table 2. Descriptive statistics of low flow data was presented in Table 2. The maximum low flow has been observed in Anger-greater station with an average $3.61 \mathrm{~m}^{3} / \mathrm{sec}$ and the lowest observation in Amen station with $0.003 \mathrm{~m}^{3} / \mathrm{sec}$. The standard deviation of the average of the low flow models provided 0.71 with maximum observed 3.01 at Anger-greater station and the minimum at Amen station with standard deviation of 0.0013 . The results of low flow data series selection using the $3 \mathrm{~d}$-slf, $7 \mathrm{~d}$-slf and 14d-slf has indicated in-significant variation based on the ANOVA (Table 3) analysis for all of the stations under this study. Hence the averages of the three data selection models have been used for trends and frequency analysis.

Table 2. Low flows for the selected stations in the Blue Nile Basin.

\begin{tabular}{|c|c|c|c|c|c|c|c|}
\hline $\begin{array}{l}\text { River/Gaging } \\
\text { station }\end{array}$ & Period & Duration & $\begin{array}{l}3 \mathrm{~d} \text {-slf } \\
\left(\mathrm{m}^{3} / \mathrm{s}\right)\end{array}$ & $\begin{array}{l}7 d-s l f \\
\left(\mathrm{~m}^{3} / \mathrm{s}\right)\end{array}$ & $\begin{array}{l}14 \mathrm{~d}-\mathrm{slf} \\
\left(\mathrm{m}^{3} / \mathrm{s}\right)\end{array}$ & Average & $\begin{array}{l}\text { Standard } \\
\text { deviation }\end{array}$ \\
\hline Amen & $1988-2005$ & 18 & 0.002 & 0.003 & 0.005 & 0.003 & 0.002 \\
\hline Andassa & $1990-2004$ & 15 & 0.988 & 0.996 & 1.023 & 1.002 & 0.018 \\
\hline Anger-greater & 1994-2004 & 11 & 3.532 & 3.856 & 3.467 & 3.618 & 0.208 \\
\hline Anger-lower & 1981-2002 & 22 & 1.478 & 1.589 & 1.794 & 1.620 & 0.160 \\
\hline Chemoga & 1973-2009 & 37 & 0.044 & 0.047 & 0.053 & 0.048 & 0.005 \\
\hline Gilgel Abay & $1980-2008$ & 29 & 1.483 & 1.483 & 1.483 & 1.483 & 0.000 \\
\hline Gilgel Beles & $1982-2005$ & 24 & 0.361 & 0.378 & 0.436 & 0.392 & 0.039 \\
\hline Gulda & $1962-2003$ & 42 & 0.117 & 0.124 & 0.136 & 0.126 & 0.010 \\
\hline Hoha & 1966-2002 & 37 & 0.831 & 0.853 & 0.882 & 0.855 & 0.026 \\
\hline Indrias & $1986-2004$ & 19 & 0.076 & 0.081 & 0.087 & 0.081 & 0.006 \\
\hline Mendel & $1987-2003$ & 17 & 0.036 & 0.038 & 0.041 & 0.038 & 0.003 \\
\hline Mugher & $1975-2002$ & 28 & 0.086 & 0.09 & 0.096 & 0.091 & 0.005 \\
\hline Neshi & $1963-2002$ & 40 & 0.209 & 0.216 & 0.227 & 0.217 & 0.009 \\
\hline Siblu & $1981-2002$ & 22 & 0.075 & 0.077 & 0.08 & 0.077 & 0.003 \\
\hline Urgessa & 1979-2002 & 24 & 0.139 & 0.145 & 0.151 & 0.145 & 0.006 \\
\hline Average & & & 0.630 & 0.665 & 0.664 & 0.653 & 0.020 \\
\hline $\begin{array}{l}\text { Standard } \\
\text { deviation }\end{array}$ & & & 0.956 & 1.033 & 0.962 & 0.984 & 0.043 \\
\hline
\end{tabular}

Table 3. ANOVA for 3d-slf, 7d-slf and 14d-slf data for the selected stations.

\begin{tabular}{ccccccc}
\hline $\begin{array}{c}\text { Source of } \\
\text { Variation }\end{array}$ & SS & dof & MS & F & P-value & F-crit \\
\hline Between Groups & 0.077813 & 2 & 0.039 & 0.015 & 0.98 & 3.22 \\
Within Groups & 105.402 & 42 & 2.51 & & & \\
Total & 105.4798 & 44 & & & & \\
\hline
\end{tabular}


The outliers found from the low flow data tie series were very few in numbers and was decided and was removed before further analysis. From all of the stations there were not higher outlier greater than the upper bound and the fewer existing ones in four stations were below the lower bound. Where one lowest outliers were found from the stations of Anger-lower, Hoha, Mendel and Neshi stations. The minimum of sustained low flow value's in Anger-lower data series was $0.03 \mathrm{~m}^{3} / \mathrm{s}$ (in 1983) which was far below the lower outlier $\left(X_{L}\right)$ bound $\left(0.08358 \mathrm{~m}^{3} / \mathrm{s}\right)$. In Hoha station sustained low flow $\left(0.001 \mathrm{~m}^{3} / \mathrm{s}\right)$ recorded in 1978 was lower than the outlier $\left(X_{L}\right)$ bounds $\left(0.00273 \mathrm{~m}^{3} / \mathrm{s}\right)$. Similarly in Mendel station the minimum sustained low flow was $0.0017 \mathrm{~m}^{3} / \mathrm{s}$ recorded in 2003 , which was lower than the lower outlier $\left(X_{L}\right)$ bound $\left(0.0023 \mathrm{~m}^{3} / \mathrm{sec}\right)$. In Neshi station $X_{L}$ the lowest low flow value was $0.049 \mathrm{~m}^{3} / \mathrm{sec}$ observed in the year of 1981 lower than the lower outlier $\left(X_{L}\right)$ bound $\left(0.056 \mathrm{~m}^{3} / \mathrm{s}\right)$. Hence these values were removed from the data series of each station.

An independence test where the assumption in the use of statistical distribution for extreme flow analysis of the sample data should be random without any serial correlation. It helps describes the strength of the relationship between a value in a series and that preceding it by one-time interval. Based on the $\mathrm{W}-\mathrm{W}$ test all the selected stations sustained low flow data series was found independent. Hence the data series was accepted for the trend and frequency analysis of the low flows. All of the selected stations low flow data series were not stationary and homogenous except one station namely Gilgel Belles which likely could be the presence of trends.

\subsection{Low Flow Trend Analysis Results}

The trend test on low flow for the selected stations were carried out by using the Mann-Kendall (MK) test as discussed in the methodology section. As presented in Table 4 and Table 5 nearly 12 of the selected station shave indicated decreasing trend $s$ of low flows. The decrement change of the low flows ranges from the selected stations range from $24.1 \%$ in Angar-great and extend to the maximum in $85 \%$ in Gulda stations. Two of the stations (Angar_lower and Hoha) from the selected stations have indicated an increasing trend with the positive change of low flow values of $43.3 \%$ and $10.1 \%$ (Figure 3). Unlike the other stations Gilgel Belles station has also indicated no significant trend.

There could be several reasons for decreasing of low flows in the Blue Nile Ba$\sin$. Some of this includes change in physical characteristics of catchment such as the land cover change in rivers basins. For instance, the change of the forest to agricultural land could largely increase runoff in the rainy season and reduce the low flows in dry seasons. This has been indicated in some of the Blue Nile Basin in different studies such as [30] land cover change in three micro watersheds (Ene-chilala, DebreMawi and Mizwa) in the Blue Nile Basin indicated that the land cover change from forest to Agriculture was 36\% from 1973 to 2013. [31] indicated an estimated change of land use from forest to agricultural land by 
Table 4. Summary statics of the Mann-Kendall trend test for the $7 \mathrm{~d}$-slf trend analysis with $\alpha=0.05$.

\begin{tabular}{cccccc}
\hline $\begin{array}{c}\text { River/Gaging } \\
\text { station }\end{array}$ & Kendall's tau & $\mathrm{S}$ & $\operatorname{Var}(\mathrm{S})$ & $\begin{array}{c}\mathrm{p} \text {-value } \\
\text { (two-tailed) }\end{array}$ & $\begin{array}{c}\text { Sen's } \\
\text { Slope }\end{array}$ \\
\hline Amen & -0.494 & -38 & 266.67 & 0.023 & $-2 \mathrm{E}-4$ \\
Andassa & -0.559 & -50 & 330.00 & 0.007 & -0.033 \\
Anger-greater & -0.556 & -25 & 0.00 & 0.029 & -1.584 \\
Anger-lower & 0.595 & 91 & 0.00 & 0.000 & 0.288 \\
Chemoga & -0.513 & -40 & 0.00 & 0.015 & -0.007 \\
Gilgel Abay & -0.604 & -180 & 1829.33 & 0.0001 & -0.062 \\
Gilgel Belles & 0.336 & 85 & 0.00 & 0.026 & 0.023 \\
Gulda & -0.566 & -397 & 6325.00 & 0.0001 & -0.005 \\
Hoha & 0.322 & 203 & 5389.00 & 0.006 & 0.006 \\
Indrias & -0.446 & -68 & 696.00 & 0.011 & -0.007 \\
Mendel & -0.433 & -52 & 0.00 & 0.020 & -0.003 \\
Mugher & -0.275 & -95 & 2289.67 & 0.049 & -0.003 \\
Neshi & -0.744 & -58 & 0.00 & 0.000 & -0.024 \\
Siblu & -0.418 & -84 & 1064.67 & 0.011 & -0.002 \\
Urgessa & 0.325 & 68 & 1094.67 & 0.043 & 0.003 \\
\hline
\end{tabular}

Table 5. Trends in the low flow for the selected stations in the Blue Nile Basin.

\begin{tabular}{ccccc}
\hline Station & Period (G.C) & Duration & Change (\%) & Trend \\
\hline Amen & $1988-2005$ & 18 & 57.1 & decreasing \\
Andassa & $1990-2004$ & 15 & 33.3 & decreasing \\
Anger_greater & $1994-2004$ & 11 & 24.1 & decreasing \\
Anger_lower & $1981-2002$ & 22 & 43.3 & Increasing \\
Chemoga & $1973-2009$ & 37 & 98 & decreasing \\
Gilgel Abay & $1980-2008$ & 29 & 68 & decreasing \\
Gilgel Belles & $1982-2005$ & 24 & - & No trend \\
Gulda & $1962-2003$ & 42 & 85 & decreasing \\
Hoha & $1966-2002$ & 37 & 10.1 & Increasing \\
Indris & $1986-2004$ & 19 & 80 & decreasing \\
Mendel & $1987-2003$ & 17 & 60 & decreasing \\
Mugher & $1975-2002$ & 28 & 60 & decreasing \\
Neshi & $1963-2002$ & 40 & 72.5 & decreasing \\
Siblu & $1981-2002$ & 22 & 47 & decreasing \\
Urgessa & $1979-2002$ & 24 & 78 & decreasing \\
\hline
\end{tabular}

more than $50 \%$ and the study also indicated decrease in low flows in the Gumara watershed (sub basin of Blue Nile Basin). [9] showed the higher changes in crop lands from forest and vegetation in Chemoga watershed (sub basin of Blue Nile 
(a) Amen river $7 d$-slf trend

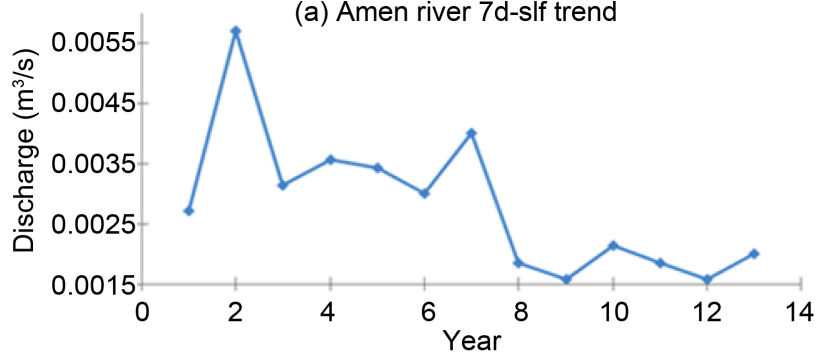

(c) Anger (Gr) 7d-slf trend
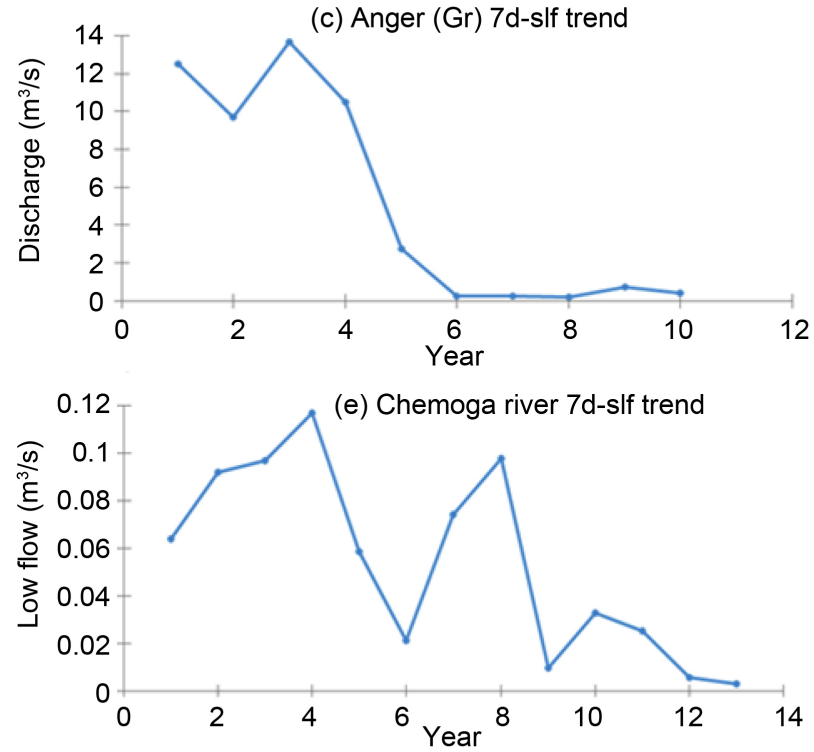

(g) Gilgel belese river 7d-slf trend
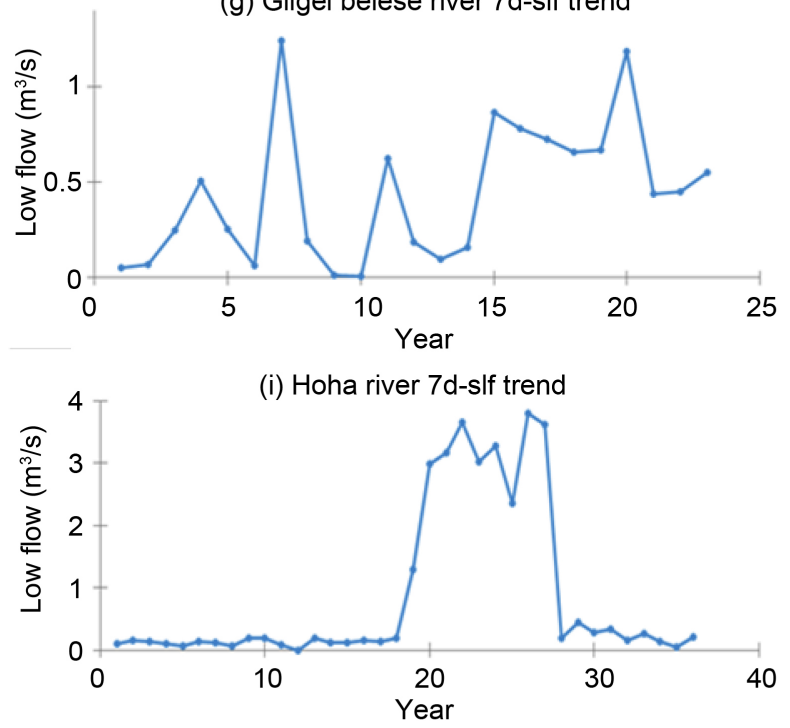

(k) Mendel river $7 \mathrm{~d}$ slf trend

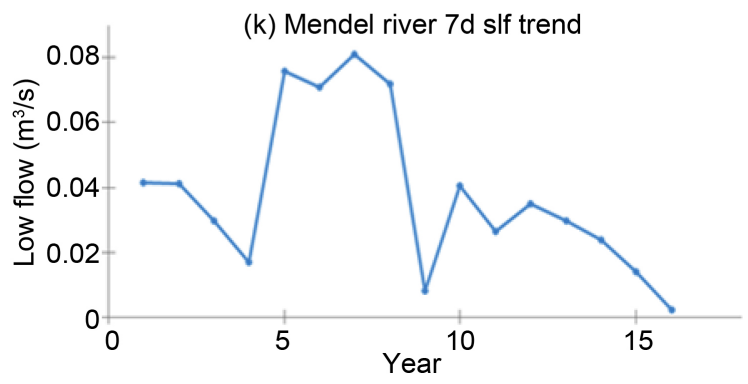

(b) Andassa river $7 \mathrm{~d}$-slf trend
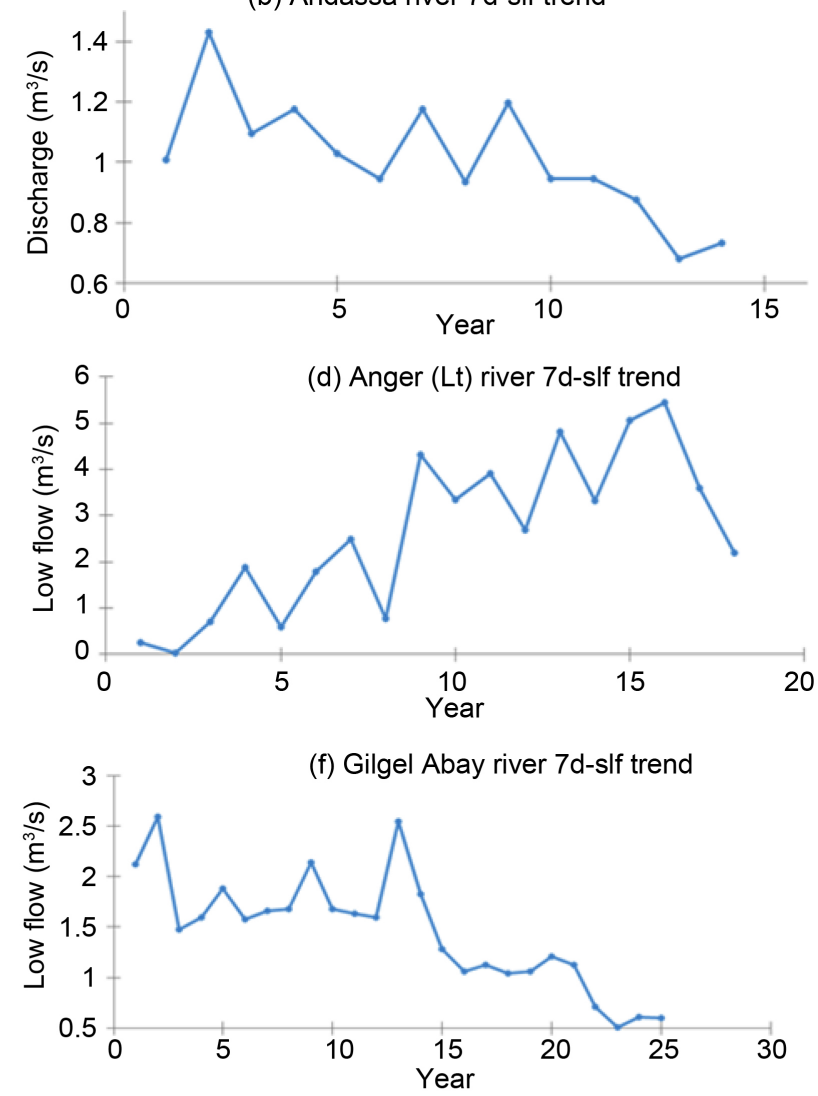

(h) Gulda river 7d-slf trend

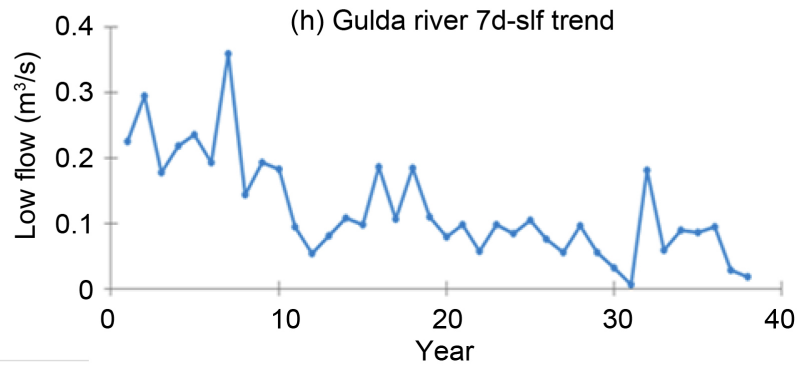

(j) Indrias river 7d slf trend
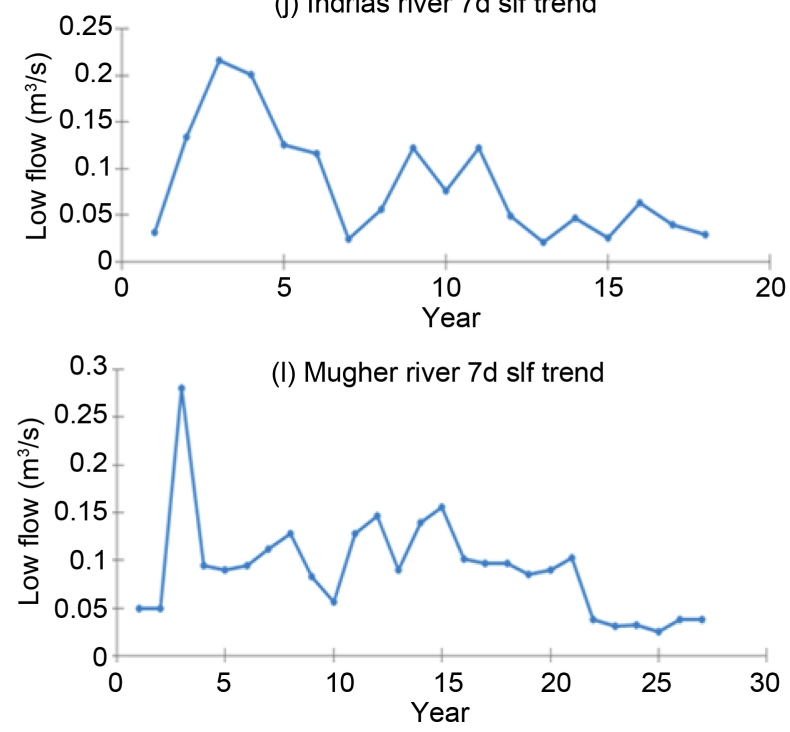

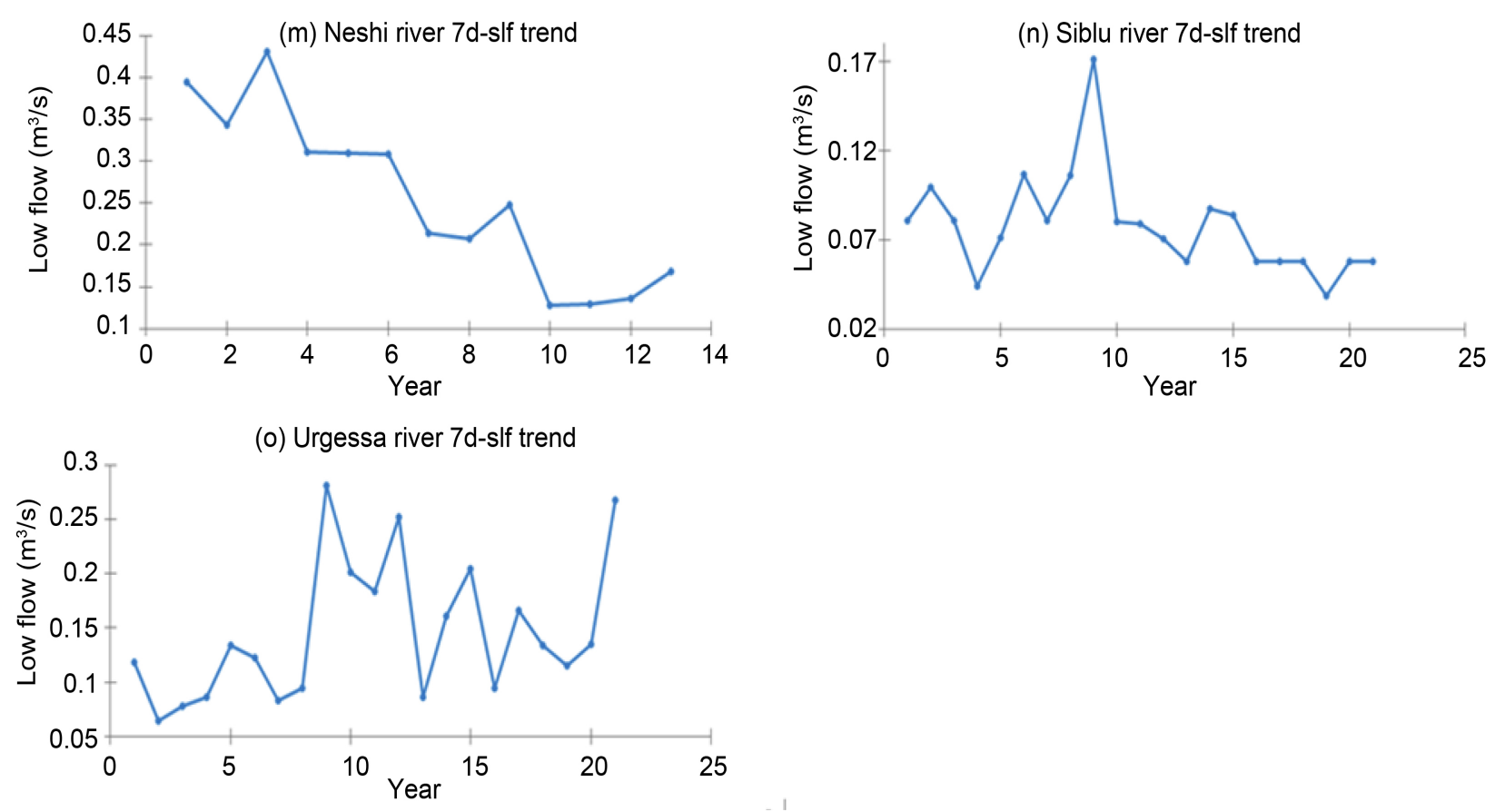

Figure 3. Trends in the 7d-slf from the river stations (a)-(o).

Basin). [32] estimated the change in land cover from forest to agricultural and from 1973 to 2005 by $43.2 \%$ and indicated a decrease in low flows during this time period [33] 1957 to 1995 in the Dembecha (part of upper Blue Nile Basin) area with decrease in forest cover from $27 \%$ in 1957 to $2 \%$ in 1982 and to $0.3 \%$ in 1995. In general, the change in land cover and poor agricultural practices increased the runoff and were one of the causes in reducing reduction the base flow and ultimately the lowest sustained low flows in the rivers of the Blue Nile which supports most of the results found in this study.

In addition, climate change could also be responsible due to an increasing temperature in the region which increases open water and soil water evaporation. This reduces the low flow to go down due to decrease of soil water in the ground water due to increasing evaporation. In Blue Nile Basin there were several sub basin specific studies which indicated an increase in trends of temperature causing an increasing evapotranspiration such studies include National Meteorological Agency [34] and [35] in the Blue Nile Basin [36] and [37] over Lake Tana basin, [38] and [39] in Gilgel Abay watershed and [40] in the upper Blue Nile Basin.

\subsection{Low Flow Frequency Analysis}

Similar to the trend analysis the data extraction was used based on the 3d-slf, $7 \mathrm{~d}$-slf and the 14d-slf data series. It was also known identified that based on the ANOVA result (Table 4) as there were no significant change the three data extracted low flow magnitude and hence for this study the frequency analysis was done based on the $7 \mathrm{~d}$-slf data series of the selected stations. 


\subsubsection{L-Moment Ratio Diagrams}

For this specific study the moment ratio diagrams were used for two purposes 1) to identify the best fit probability distribution for each station and 2) to select homogeneous regions based on the best fit probability distributions and statistical tests for regionalization purpose. Based on the results from the L-MRD (Figure 4) from the selected 15 stations it was found that 10 stations were fitted with Weibul probability distribution for 7d-slf data. The stations were Amen, Anger-greater, Anger-lower, Gilgel Beles, Gilgel Abay, Indrias, Mendel Neshi and Urgessa. Similarly, Andassa and Gudla stations were best fit with Log normal probability distributions. Hora, Mugher and Chemoga river stations were best fit for General Parent probability distributions (Table 6).

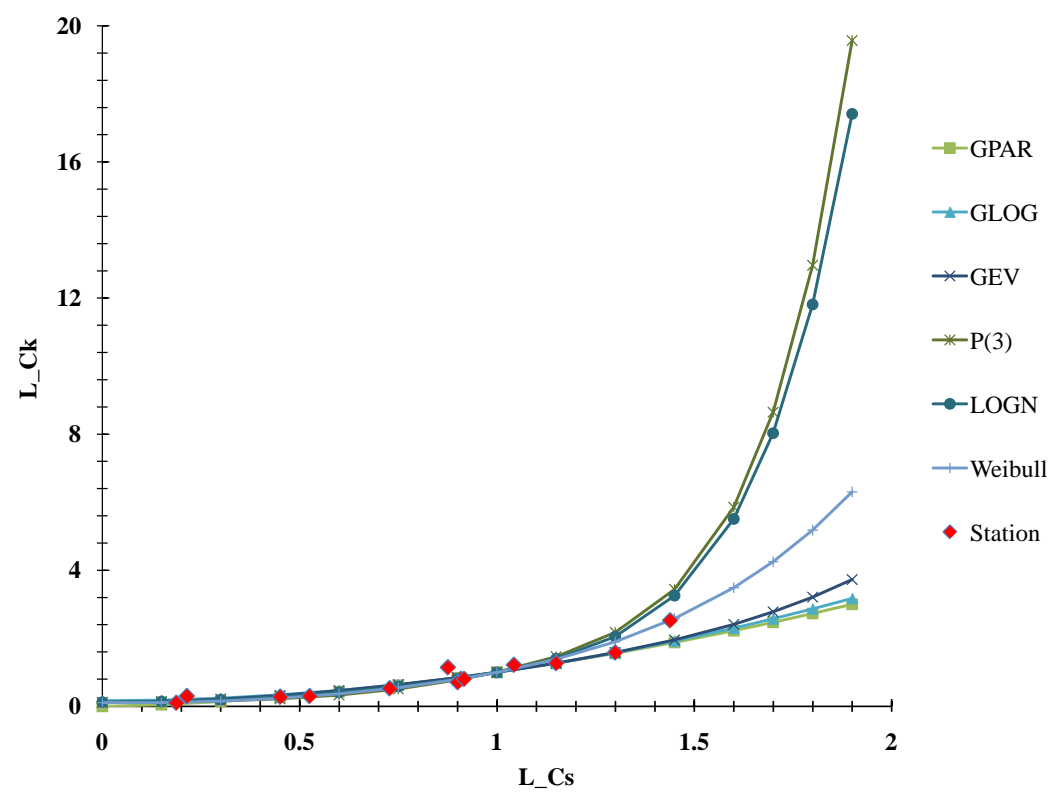

Figure 4. L-MRD for the selected flow gaging stations in the Blue Nile Basin.

Table 6. Probability distributions for the selected stations used in this study.

\begin{tabular}{cc}
\hline Stations & Probability distribution \\
\hline Amen & Weibull \\
Andassa & Log Normal (LGN) \\
Anger (Gr) & Weibull \\
Anger (Lt) & Weibull \\
Chemoga & Generalized Extreme Value (GEV) \\
Gilgel Abay & Weibull \\
Gilgel Beles & Weibull \\
Gulda & Log Normal (LGN) \\
Hoha & Generalized Extreme Value (GEV) \\
Indrias & Weibull \\
Mendel & Weibull \\
Mugher & Generalized Extreme Value (GEV) \\
Neshi & Weibull \\
Siblu & Weibull \\
Urgessa & Weibull \\
&
\end{tabular}




\subsubsection{Parameter Estimation}

As discussed in the methodology section the parameter for the selected probability distributions, parameter has been estimated by using the PWM as summarized in Table 7. For all of the selected stations under for three groups of probability distributions the Probability Weighted Moment was used to estimate the parameters for computing the quantiles. Where 10 of the stations were fitted Weibull probability distribution while the reaming 2 and 3 stations with LNG and GEV with group 2 and 3 respectively (Table 7) as group of homogenous region.

Table 7. Low flow best fit probability distributions with parameter estimation techniques.

\begin{tabular}{|c|c|c|c|}
\hline Rivers/gaging stations & $\begin{array}{l}\text { Probability } \\
\text { distribution }\end{array}$ & $\begin{array}{c}\text { Parameter } \\
\text { estimation method }\end{array}$ & $\begin{array}{l}\text { Homogenous } \\
\text { groups }\end{array}$ \\
\hline Amen & \multirow{10}{*}{ Weibul } & \multirow{10}{*}{ PWM } & \multirow{10}{*}{ Group-1 } \\
\hline Anger_greater & & & \\
\hline Anger_lower & & & \\
\hline Gilgel Beles & & & \\
\hline Gilgel Abay & & & \\
\hline Indrias & & & \\
\hline Mendel & & & \\
\hline Neshi & & & \\
\hline Siblu & & & \\
\hline Urgessa & & & \\
\hline Andassa & \multirow[t]{3}{*}{ Log Normal (LGN) } & \multirow[t]{2}{*}{ PWM } & \multirow[t]{2}{*}{ Group-2 } \\
\hline Gulda & & & \\
\hline Hora & & \multirow{3}{*}{ PWM } & \multirow{3}{*}{ Group-3 } \\
\hline Mugher & $\begin{array}{c}\text { Generalized Extreme } \\
\text { Value (GEV) }\end{array}$ & & \\
\hline Chemoga & & & \\
\hline
\end{tabular}

\subsubsection{Quintiles Estimations}

Using the selected probability distributions and parameter estimations the low flow parameters have been estimated for return period starting from 2 - 500 years as indicated in Figure 5. The long term quantiles for some of the stations showed that there would be rapid diminishing in magnitudes of low flows. In some the stations such as in Belles and Chemoga rivers the long term return period low flows has resulted no flow after 2 years return period. This might indicate there would be drying up of the river flows in dry seasons. Where this needs water management plans to counteract with the upcoming extreme events to supplement the productivity with irrigation as irrigation in dry season requires substantial base/low flows of the river. In addition, it also needs watershed management to increase the recharge to sustain the environmental flows which are related with the low flow situation in the river. 


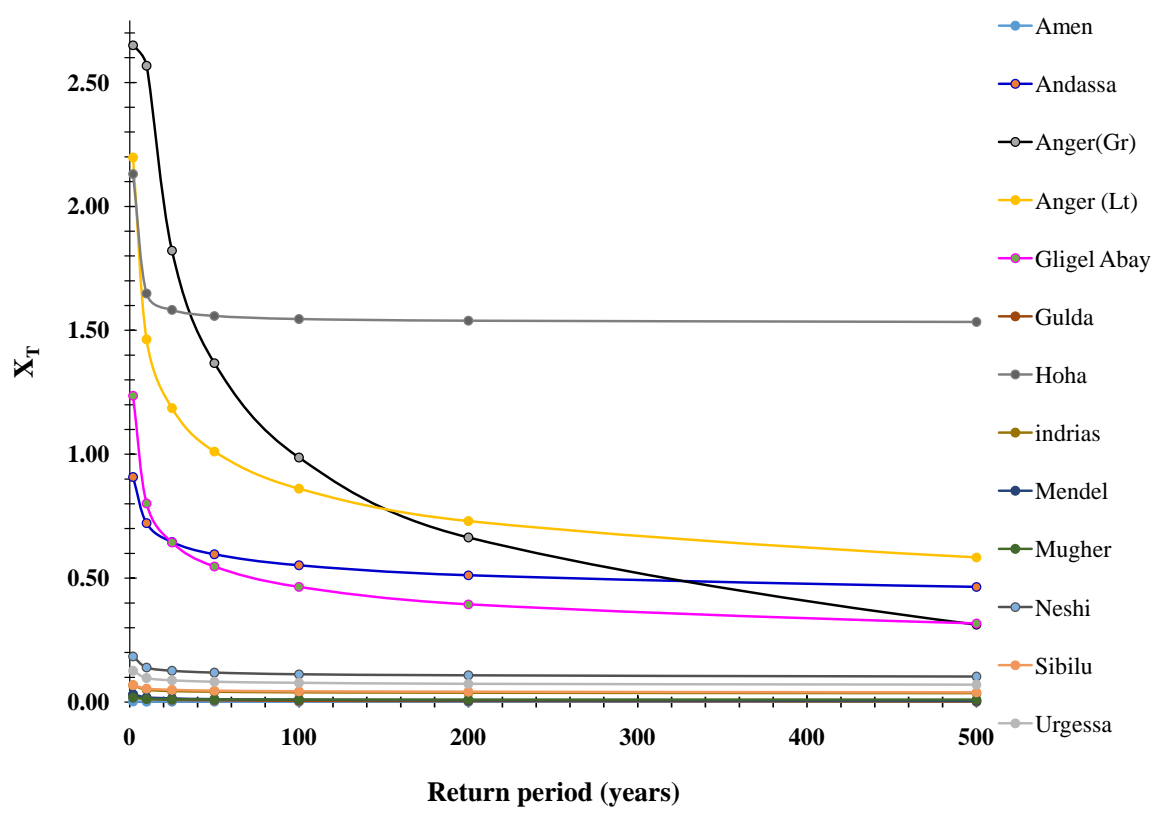

Figure 5. Quantile estimation of 7d-slf for the selected station in the Blue Nile Basin.

\subsection{Regional Low Flow Analysis}

The first step in regionalization was identifying the homogeneous regions or clustering based on different techniques. In this study the moment ratio diagram specifically the L-MRD was used for identifying the homogeneous groups. In addition the Coefficient of Variation of Coefficient of Variation (C-C) test was also carried out to further verify the homogenous regions. Based on the results from the L-MRD and CC based test the homogeneous regions were categorized as indicated in Table 8, where 10 stations were assigned as homogenous region group-1 with Weibull as the best fit probability distribution. While the remaining 2 and 3 stations assigned homogenous groups 2 and 3 with Log Normal (LGN) and Generalized Extreme Value (GEV) as the best fit probability distribution. Based on each homogenous group and best fit probability distribution the regional low flow curve equations to quantify the standardized quantiles of each group are provided in Table 8. Hence the regional standardized equations could be used for estimating standardized quantile for any ungaged site in the homogenous region and further to estimate the stream flow quantiles from the catchment characteristics derived average stream flow.

Using the catchment characteristics as in order to drive the low flows the best fit nonlinear regression was established. The relation between the predicted and observed low flows indicated a good predicting capability with an $\mathrm{R}^{2}$ of 0.73 (Figure 6). The sensitive parameters during calibration of non-linear regression equation were area of drainage basins and rainfall sequentially followed by slope of the watershed. Hence using the regional growth curves under Table 8 and Equation (20) could help to estimate long term quantiles for ungaged catchment.

$$
\bar{Q}=0.201 A^{1.0412} S^{-0.013} R^{-1.089} F^{0.074}
$$




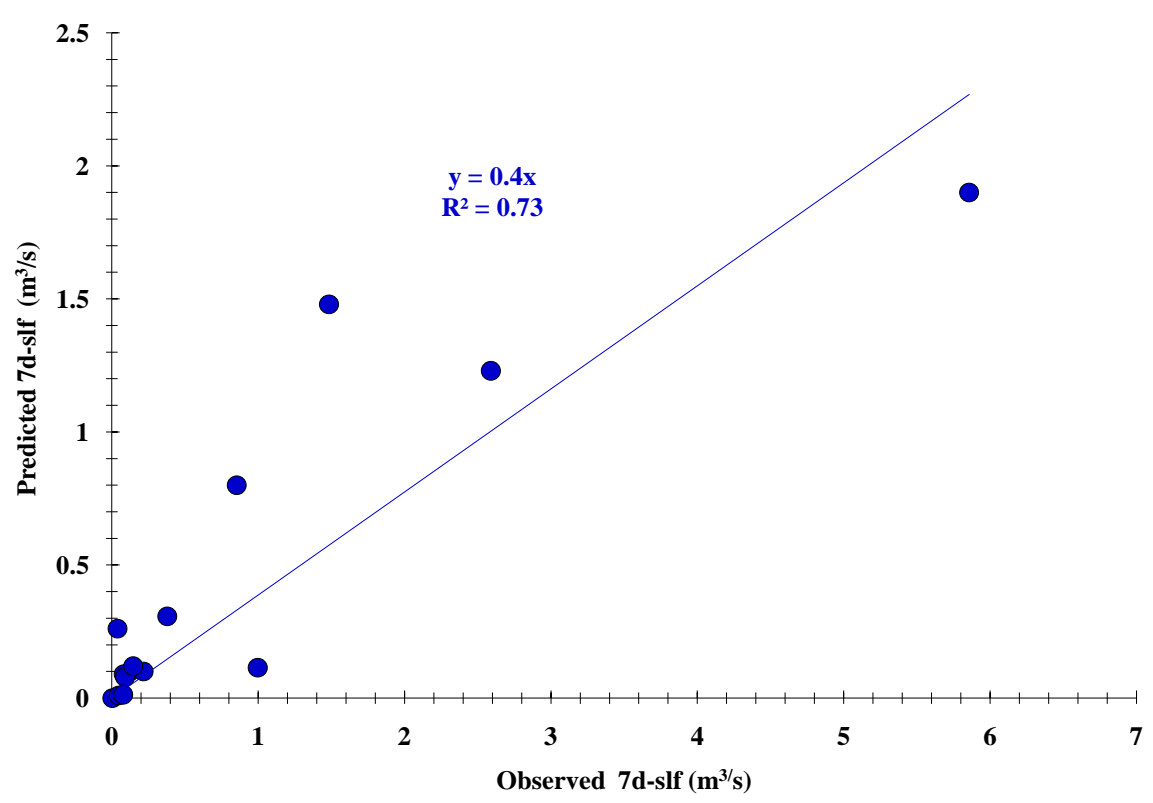

Figure 6. Predicted and observed 7d-slf using catchment characteristics.

Table 8. Summary of regional growth curve equation.

\begin{tabular}{|c|c|c|}
\hline Stations & $\begin{array}{c}\text { Best fit } \\
\text { Probability } \\
\text { distribution }\end{array}$ & $\begin{array}{l}\text { Regional low flow } \\
\text { Growth curve equations. }\end{array}$ \\
\hline Amen & \multirow{9}{*}{ Weibull } & \multirow[b]{5}{*}{$Q_{T}=0.059+1.039[\log (1 / T)]^{1 / 3.85}$} \\
\hline Anger_Great & & \\
\hline Anger_Lower & & \\
\hline Gilgel Beles & & \\
\hline $\begin{array}{c}\text { Gilgel Abay } \\
\text { Indrias }\end{array}$ & & \\
\hline Mendel & & \\
\hline Neshi & & \multirow[b]{4}{*}{$Q_{T}=0.073+0.653[1-(-\log 1 / T)]^{1 / 4.57}$} \\
\hline Siblu & & \\
\hline Urgessa & & \\
\hline $\begin{array}{l}\text { Andassa } \\
\text { Gulda }\end{array}$ & Log Normal (LGN) & \\
\hline $\begin{array}{l}\text { Hoha } \\
\text { Mugher }\end{array}$ & $\begin{array}{l}\text { Generalized Extreme } \\
\text { Value (GEV) }\end{array}$ & \multirow[t]{2}{*}{$Q_{T}=\mathrm{e}^{0.33+U 0.468}$} \\
\hline Chemoga & & \\
\hline
\end{tabular}

\section{Conclusion}

The results in this study have indicated mainly a decrease in low flows values for the selected stations in the Blue Nile Basin. This was attributed to the catchment dynamics especially land cover change and climate change over the river basins. In addition to that, the current vegetation cover in basin is largely converted to 
the eucalyptus tree which consumes high water from the soil due to large evapotranspiration. Hence watershed management targeting the main changes in watersheds mentioned above with afforestation and climate adaptation should be in place to mitigate and keep the health of rivers. The L-Moment ratio diagram provides a practical method to identify the underlying distribution for a given station. The use of the L-Moment ratio diagram was very convenient that one can compare the fit of several distributions using which are superior to conventional moment ratios because L-moments are less biased than ordinary moments. Low flow frequency analysis has indicated that the long term low flow quantiles for short and long term return periods indicted by large decreasing low flow quantiles even in some of the stations were found the "no flow". Using the growth curve and the relation between low flows with catchment characteristics could help for estimating the low flows quantiles for water resource planning and management.

\section{References}

[1] Smaktin, V.U. (2001) Low Flow Hydrology: A Review. Journal of Hydrology, 240, 147-186. https://doi.org/10.1016/S0022-1694(00)00340-1

[2] World Meteorological Organization WMO (2008) Manual on Low-Flow: Estimation and Prediction. Operational Hydrology Report No. 50.

[3] Tallaksen, L.M., Madsen, H. and Clausen, B. (1997) On the Definition and Modeling of Stream Flow Drought Duration and Deficit Volume. Hydrological Sciences Journal, 42, 15-33. https://doi.org/10.1080/02626669709492003

[4] Bickerton, M., Petts, G., Armitage, P. and Castella, E. (1993) Assessing the Ecological Effects of Groundwater Abstraction on Chalk Streams: Three Examples from Eastern England. River Research and Applications, 8, 121-134.

https://doi.org/10.1002/rrr.3450080115

[5] Meier, K.B., Brodie, J.R., Schulze, R.E., Smithers, J.C. and Mnguni, D. (1997) Modelling the Impacts of Riparian Zone Alien Vegetation on Catchment Water Resources using the ACRU Model. Proceedings of the Eighth South African National Hydrology Symposium, Pretoria, 1 November 1997, 13.

[6] Eheart, J.W. and Tornil, D.W. (1999) Low-Flow Frequency Exacerbation by Irrigation Withdrawals in the Agricultural Mid-West under Various Climate Change Scenarios. Water Resources Research, 35, 2237-2246.

https://doi.org/10.1029/1999WR900114

[7] Middelkoop, H., Daamen, K., Gellens, D., Grabs, W., Kwadijk, J.C.J., Lang, H., Parmet, B., Schadler, B., Schulla, J. and Wilke, K. (2001) Impact of Climate Change on Hydrological Regimes and Water Resources Management in the Rhine Basin. Climate Change, 49, 105-128. https://doi.org/10.1023/A:1010784727448

[8] Wagener, T., Sivapalan, M., McDonnell, J., Hooper, R., Lakshmi, V., Liang, X. and Kumar, P. (2004) Predictions in Ungaged Basins as a Catalyst for Multidisciplinary Hydrology. Eos Transaction American Geophysical Union, 85, 451-457.

[9] Bewket, W. and Sterk, G. (2005) Dynamics in Land Cover and Its Effect on Stream Flow in the Chemoga Watershed, Blue Nile Basin, Ethiopia. Hydrological Processes, 19, 445-458. https://doi.org/10.1002/hyp.5542

[10] Amsalu, A., Leo, S. and Jan de, G. (2007) Long-Term Dynamics in Land Resource 
Use and the Driving Forces in the Beressa Watershed, Highlands of Ethiopia. Journal of Environmental Management, 83, 448-459. https://doi.org/10.1016/j.jenvman.2006.04.010

[11] Fisseha, G., Heluf, G., Kibebew, K., Birru, Y. and Bobe, B. (2011) Analysis of Land Use/Land Cover Changes in the Debre-Mewi Watershed at the Upper Catchment of the Blue Nile Basin, North West Ethiopia. Journal of Biodiversity and Environmental Sciences, 1, 184-198.

[12] Temesgen, E., Meseret, B.A., Adugnaw, T., Debebe, L.Y., Azalu, A.G., Seifu, A.T., Mengiste, A.M., Fasikaw, A.Z., Mamaru, A.M. and Tammo, S. (2014) Biohydrology of Low Flows in the Humid Ethiopian Highlands: The Gilgel Abay Catchment. Biologia, 69, 1502-1509. https://doi.org/10.2478/s11756-014-0462-9

[13] Conway, D. (2005) From Headwater Tributaries to International River: Observing and Adapting to Climate Variability and Change in the Nile Basin. Global Environmental Change, 15, 99-114. https://doi.org/10.1016/j.gloenvcha.2005.01.003

[14] Sutcliffe, J.V. and Parks, Y.P. (1999) The Hydrology of the Nile (No. 5). International Association of Hydrological Sciences, Wallingford.

[15] Conway, D. (2000) The Climate and Hydrology of the Upper Blue Nile River. The Geographical Journal, 166, 49-62. https://doi.org/10.1111/j.1475-4959.2000.tb00006.x

[16] Conway, D. (1997) A Water Balance Model of the Upper Blue Nile in Ethiopia. Hydrological Sciences Journal, 42, 265-286. https://doi.org/10.1080/02626669709492024

[17] Yasir, S.A., Crosato, A., Mohamed, Y.A., Abdalla, S.H. and Wright, N.G. (2014) Sediment Balances in the Blue Nile River Basin. International Journal of Sediment Research, 29, 316-328. https://doi.org/10.1016/S1001-6279(14)60047-0

[18] McCuen, R.H. (1998) Hydrologic Design and Analysis. Prince Hall, Newark, 814.

[19] Kendall, M.G. (1975) Rank Correlation Methods. 4th Edition, Charles Griffin, London.

[20] Kahya, E. and Kalayci, S. (2004) Trend Analysis of Streamflow in Turkey. Journal of Hydrology, 289, 128-144. https://doi.org/10.1016/j.jhydrol.2003.11.006

[21] Lu, X. (2005) Spatial Variability and Temporal Change of Water Discharge and Sediment Flux in the Lower Jinsha Tributary: Impact of Environmental Changes. River Research and Applications, 21, 229-243. https://doi.org/10.1002/rra.843

[22] Partal, T. and Kahya, E. (2006) Trend Analysis in Turkish Precipitation Data. Hydrological Process, 20, 2011-2026.

[23] Arun, M., Sananda, K. and Anirban, M. (2012) Rainfall Trend Analysis by Mann-Kendell Test: A Case Study of North-Eastern Part of Cuttack District, Orissa. International Journal of Geology, Earth and Environmental Sciences, 2, 70-78.

[24] Grubbs, F. and Becks, G. (1972) Extension of Sample Sizes and Percentage Points for Significance Test of Outlying Observations. Technometrrics, 14, 847-854.

[25] Wald, A. and Wolfowitz, J. (1943) An Exact Test for Randomness in the Nonparametric Case Based on Serial Correlation. The Annals of Mathematical Statistics, 14, 378-388. https://doi.org/10.1214/aoms/1177731358

[26] Mann, H.B. and Whitney, D.R. (1947) On the Test Whether One of Two Random Variables in Stochastically Larger than the Other. The Annals of Mathematical Statistics, 18, 50-60. https://doi.org/10.1214/aoms/1177730491

[27] Hosking, J.R.M. (1986) The Value of Historical Data in Flood Frequency Analysis. Water Resources Research, 22, 1606-1612. 
[28] Rao, A.R. and Hamed, K.H. (2000) Flood Frequency Analysis. CRC Press, Boca Raton.

[29] Greenwood, J.A., Landwehr, J.M., Matalas, N.C. and Wallis, J.R. (1979) Probability Weighted Moments: Definition and Relation to Parameters of Several Distributions Expressible in Inverse Format. Water Resources Research, 15, 1049-1054. https://doi.org/10.1029/WR015i005p01049

[30] Asres, R.S., Tilahun, S.A., Ayele, G.T. and Melesse, A.M. (2016) Analyses of Land Use Land Cover Change Dynamics in the Upland Watersheds of Upper Blue Nile Basin. In: Melesse, A.M. and Abtew, W., Eds., Landscape Dynamics, Soil and Hydrological Processes in Varied Climates, Springer, Cham, 73-91. https://doi.org/10.1007/978-3-319-18787-7_5

[31] Chakilu, G. and Moges, M.A. (2017) Assessing the Land Use/Cover Dynamics and Its Impact on the Low Flow of Gumara Watershed, Upper Blue Nile Basin, Ethiopia. Hydrology: Current Research, 7, 268. https://doi.org/10.4172/2157-7587.1000268

[32] Haile, A., Rientjes, T., Kebede, E., Mannaerts, C., Habib, E. and Steenhuis, T. (2011) Changes in Land Cover, Rainfall and Stream Flow in Upper Gilgel Abbay Catchment, Blue Nile Basin-Ethiopia. Hydrology and Earth System Sciences, 15, 19-79.

[33] Zeleke, G. and Hurni, H. (2001) Implications of Land Use and Land Cover Dynamics for Mountain Resource Degradation in the Northwestern Ethiopian Highlands. Mountain Research and Development, 21, 184-191. https://doi.org/10.1659/0276-4741(2001)021[0184:IOLUAL]2.0.CO;2

[34] National Meteorological Agency, NMA (2009) Annual Technical Report.

[35] Taye, M.T., Ntegeka, V., Ogiramoi, N.P. and Willems, P. (2011) Assessment of Climate Change Impact on Hydrological Extremes in Two Source Regions of the Nile River Basin. Hydrology and Earth System Sciences, 15, 209-222. https://doi.org/10.5194/hess-15-209-2011

[36] Setegn, S., Rayner, D., Melesse, A., Dargahi, B. and Srinivasan, R. (2011) Impact of Climate Change on the Hydroclimatology of Lake Tana Basin, Ethiopia. Water Resources Research, 47, W04511. https://doi.org/10.1029/2010WR009248

[37] Deksyos, T. and Abebe, T. (2008) Assessing the Impact of Climate Change on the Water Resources of Lake Tana Sub-Basin. Research Report, Addis Abeba.

[38] Abdo, K., Fiseha, B., Rientjes, T., Gieske, A. and Haile, A. (2009) Assessment of Climate Change Impacts on the Hydrology of Gilgel Abay Catchment in Lake Tana Basin, Ethiopia. Hydrological Processes, 23, 3661-3669. https://doi.org/10.1002/hyp.7363

[39] Habtom, M. (2009) Evaluation of Climate Change Impact on Upper Blue Nile Basin Reservoir. Doctoral Dissertation, MSc Thesis, Case Study on Gilgel Abay Reservoir.

[40] Girma, Y., Andreja, J. and Ann, V. (2009) Hydrological Response of a Catchment to Climate Change in the Upper Beles River Basin, Upper Blue Nile, Ethiopia. UNESCO-IHE Institute for Water Education, Department of Hydro Informatics and Knowledge Management, Nile Basin Water Engineering Scientific. 